Sharif University of Technology
Scientia Iranica
Transactions E: Industrial Engineering
http://scientiairanica.sharif.edu
IRAN ICA

\title{
Economic efficiency of the application of artificial air cooling for normalization of thermal conditions in oil mines
}

\author{
V.R. Alabyeva,*, M.N. Kruk ${ }^{\mathrm{b}}$, T.P. Bazhina ${ }^{\mathrm{a}}$, A.S. Semenov ${ }^{\mathrm{c}}$, and V.I. Demin ${ }^{\mathrm{a}}$ \\ a. Department of Life Safety, Kuban State Technological University, 350072, 2 Moskovskaya Str., Krasnodar, Russian Federation. \\ b. Department of Organization and Management, Saint-Petersburg Mining University, 199106, 21 Line Vassilievsky Isl., bld. 2, \\ Saint-Petersburg, Russian Federation. \\ c. Department of Mining Engineering, Mining Faculty, Saint-Petersburg Mining University, 199106, 21 Line Vassilievsky Isl., bld. \\ 2, Saint-Petersburg, Russian Federation.
}

Received 1 March 2018; received in revised form 22 September 2018; accepted 22 October 2018

\section{KEYWORDS}

Oil mine;

Thermal regime;

Refrigeration

technology;

Technical solutions;

Temperature;

Air conditioning;

Working conditions;

Economic efficiency.

\begin{abstract}
This work substantiates a technical solution for improving the working conditions for the thermal factor in oil extraction by the thermoshaft method using the mine refrigeration technology. A review of manufacturers and technical characteristics of refrigeration technology in Russia, CIS countries, and Western Europe was conducted. For the selected set, the economic efficiency of the project was assessed, and a conclusion was made about the feasibility of implementing this project solution. It was shown that the use of a water-cooling machine in the mine air conditioning system would reduce the air temperature in the oil production gallery to the required values and allow abandoning the long-term construction of a surface stationary refrigeration station. The normalization of the thermal regime reduces the costs of benefits and compensation for work in harmful labor conditions and improves the quality of service of production wells by operators. The project for the introduction of air conditioning has a high level of profitability, and its payoff will occur in the second year of operation.
\end{abstract}

(C) 2020 Sharif University of Technology. All rights reserved.

\section{Introduction}

Yaregskoye field of heavy high-viscosity oil is unique in Russia. This is the only place where hydrocarbon production is carried out by an underground thermoshaft method. The basis of the thermoshaft method is a decrease in viscosity and an increase in oil mobility due to the formation heating up to a temperature of $70-90^{\circ} \mathrm{C}$ with the aid of a heat transfer fluid pumped into the oil-bearing horizon. Saturated water vapor with a temperature of $170-200^{\circ} \mathrm{C}$ is used as a heat

*. Corresponding author. Tel.: 861 255-84-01 E-mail address: avr.09@mail.ru (V.R. Alabyev)

doi: $10.24200 /$ sci.2018.50549.1753 transfer fluid. The main development system (70\%) is the underground surface system. In other cases, a one-dimensional development system is used [1].

With this oil production technology, even at shallow depths with the natural temperature of the enclosing rocks $\left(10-12^{\circ} \mathrm{C}\right)$, there are a number of problems associated with maintaining the permissible air temperature, which can reach $50-55^{\circ} \mathrm{C}$ in drilling galleries and ventilation openings [2,3], significantly exceeding the permissible standards [4]. According to the requirements of the safety rules for the Russian oil mines, the air temperature in the existing workings should not exceed $26^{\circ} \mathrm{C}$ at relative humidity up to $90 \%$. In those workings, where there is no permanent presence of people during the shift, air temperature up to $36^{\circ} \mathrm{C}$ is allowed [5]. 
In the process of oil production, the thermal regime of the drilling galleries is mainly formed due to the thermal divisions of the enclosing rocks stipulated by the action of the heating coolant, the breakthroughs of the heating coolant from the side of the roof and the bottomhole area, and the heat released by the oily liquid during direct contact with the air in the process of its collection and transportation by gravity method [6]. The increased temperature and air humidity lead to rapid fatigue, reduced attention and labor productivity, overheating of the working organism, and perhaps various accidents $[7,8]$.

\section{Materials and methods}

The authors analyzed enough scientific research. It was established that the ventilation measures associated with the sectional ventilation of sloping blocks, the choice of rational ventilation schemes for operating panels, and an increase in the speed of air movement in the drilling galleries were used to regulate the thermal regime in oil mines. Mining measures are used to reduce the negative impact of heat emissions from various sources on the increase of air temperature in drilling galleries and workings of ventilation horizons. These measures include the definition of the permissible extent of mine workings based on the magnitude of heat inflows [9,10], the use of a closed oil collection system, and the thermal insulation of steam steampipes and pipelines for pumping oily liquid. The issue of reducing heat emissions from the mount Massif by the concreting and thermal insulation of the walls of drilling galleries, as well as their irrigation with cold water, is studied [11].

However, as shown by field observations, these measures are clearly not enough to meet the required temperature standards. An increase, for example, in supplying air to the mine by 1.5 leads to a decrease in air temperature in the drilling galleries by only $1-2^{\circ} \mathrm{C}$ [2]. Therefore, more effective measures are required. In this issue, one cannot use the experience of foreign countries since the extraction of high-viscosity oil, for example in Canada, is conducted using technologies that do not require the constant presence of people under the ground [12].

The experience of developing reservoir deposits in Germany, Poland, the Czech Republic, and Ukraine shows that artificial air cooling is used at depths with the $45^{\circ} \mathrm{C}$ and higher temperatures of the host rocks to normalize the thermal working conditions in the productive workings. For cooling, underground stationary and mobile Air-Conditioning Systems for Mine Air (ACSMA) and central cooling systems with the superficial arrangement of refrigeration stations are used [13]. Proceeding from the analogy with reservoir deposits, we believe that it is possible to apply artificial air cooling to improve the thermal regime of the operating sloping blocks of oil mines, which belongs to the thermal engineering group of control methods [14]. However, up to now, ACSMAs have never been used in Russian oil mines, there is no experience of their exploitation, and the economic feasibility of their use is questionable.

Consequently, the authors justified design solutions for applying refrigeration technology to improve and normalize thermal conditions in drilling galleries in the extraction of oil underground. The authors analyzed the economic efficiency of the introduction of refrigeration technology with respect to an example of a typical oil-extracting gallery of the Yaregskoye field.

\section{Results and discussion}

The improvement of thermal conditions by means of refrigerating machines is considered for an example of a typical oil-extracting gallery of the Yaregskoye field. Hygrothermal air parameters along the way of their movement from the air supplying shaft trunk to the drilling gallery (Figure 1) are presented in Table 1 .

As shown by the results of thermal surveys, the air temperature on the airborne horizon does not exceed the norms permitted by the safety rules. However, it reached its critical value and amounted to $26.0^{\circ} \mathrm{C}$ already at the entrance of the drilling gallery. A major increase in air temperature is observed in the drilling gallery itself and in the outgoing air jet in the slope, which is caused by the above factors. According to the results of thermal surveys, it is determined that the

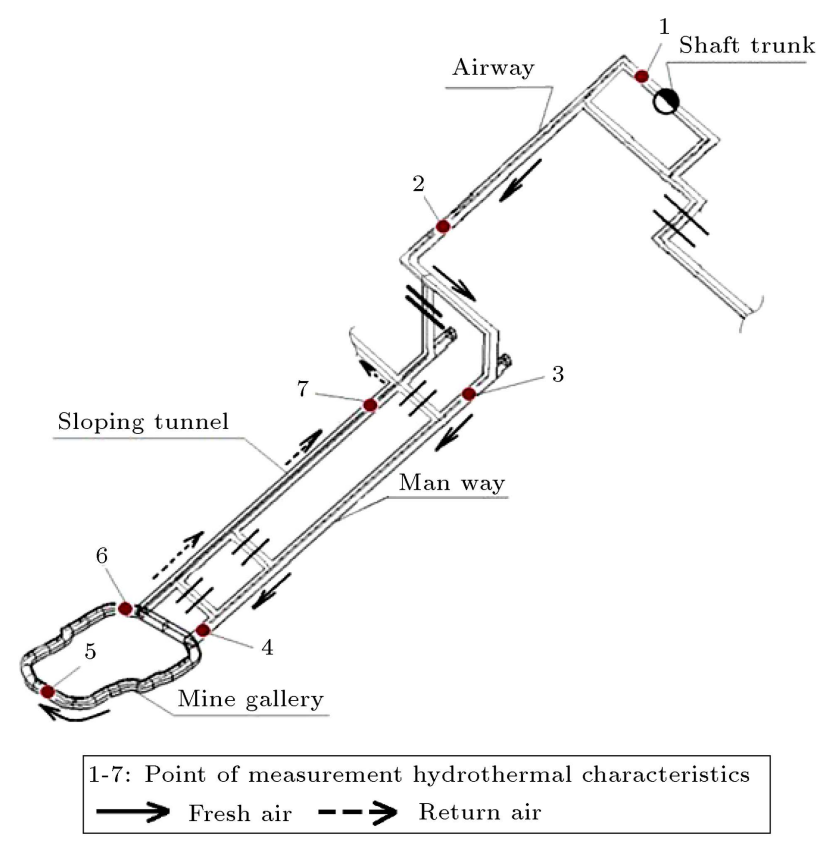

Figure 1. The scheme of location of points of measurements along the route of the oil gallery. 
Table 1. Heat and humidity parameters of the air along the route of the oil gallery.

\begin{tabular}{ccccc}
\hline $\begin{array}{c}\text { The number of } \\
\text { the measurement } \\
\text { point (Figure 1) }\end{array}$ & $\begin{array}{c}\text { The air } \\
\text { temperature, } \\
\boldsymbol{t}\left({ }^{\circ} \mathbf{C}\right)\end{array}$ & $\begin{array}{c}\text { Relative } \\
\text { humidity } \\
(\mathbf{\%})\end{array}$ & $\begin{array}{c}\text { The moisture } \\
\text { content of the air } \\
(\mathbf{g} / \mathbf{k g})\end{array}$ & $\begin{array}{c}\text { The enthalpy } \\
\text { of the air } \\
(\mathbf{k J} / \mathbf{k g})\end{array}$ \\
\hline 1 & 6 & 46 & 2.6 & 12.6 \\
2 & 18 & 48 & 6.0 & 33.3 \\
3 & 21 & 43 & 6.5 & 37.6 \\
4 & 26 & 39 & 8.0 & 46.5 \\
5 & 37 & 65 & 25.5 & 102.8 \\
6 & 39 & 60 & 26.3 & 106.9 \\
7 & 49 & 78 & 60.5 & 205.9 \\
\hline
\end{tabular}

cooling demand of the drilling gallery, provided that the air temperature at the end of the slope does not exceed $35.0^{\circ} \mathrm{C}$, is about $1000 \mathrm{~kW}$ (Figure 2).

Usually, in an underground oil-producing enterprise, 5-6 drilling galleries are in operation at the same time. Based on the assumption that the remaining drilling galleries have the same cold demand, it can be concluded that normalizing the thermal conditions within the enterprise will require a cooling capacity of about 5-6 MW. The realization of such cooling capacity by underground cooling means in oil mines' conditions is impossible, since the issues of placing refrigerator machines and removing the heat of refrigerant condensation in mine workings seem to be an intractable task. In such cases, it is necessary to construct an ACSMA with a surface location of the refrigeration station. However, the construction period for such facilities takes at least $4-5$ years (the development of an air conditioning project, its expertise, certification of foreign refrigeration equipment, construction of a

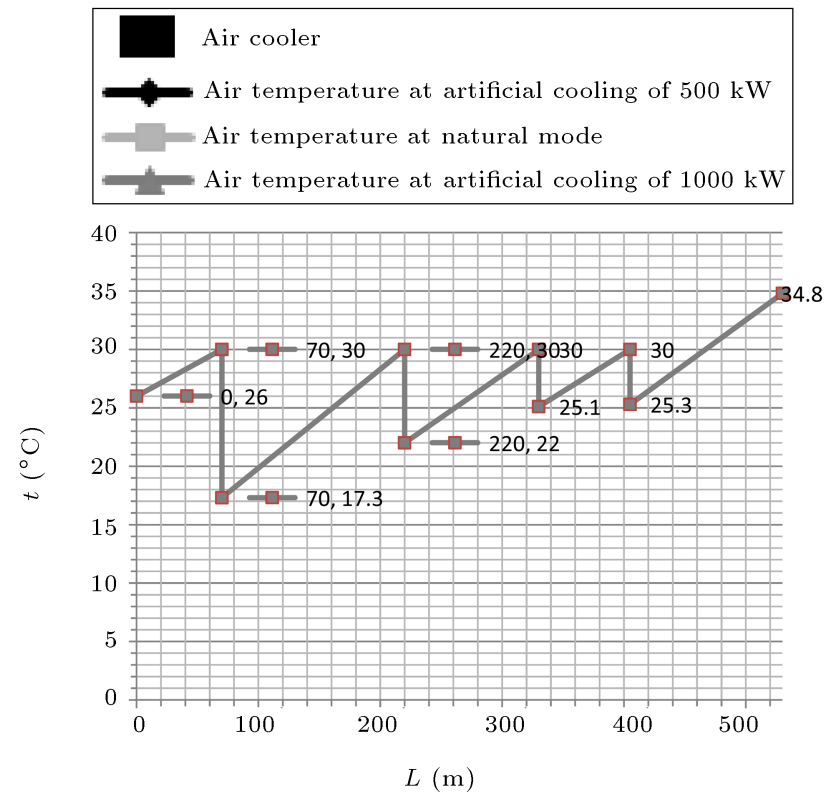

Figure 2. The change in temperature oil gallery. surface refrigeration plant complex, equipment installation, pipelines, etc.) and the problem of normalizing thermal conditions must be solved today already.

At the initial stage, it is proposed that an underground cooling machine of a water-cooling type with a power of $500 \mathrm{~kW}$ be introduced to normalize the thermal conditions in one drilling gallery. For this purpose, the compressor-and-condenser unit of the refrigeration machine is located in the broadening of the air-producing horizon, and the air coolers (2 pieces of $250 \mathrm{~kW}$ ) are located directly in the drilling gallery itself at points where the air temperature exceeds the norms allowed by the safety rules (Figure 3 ). In this case, the air temperature at the outlet of the drilling gallery does not exceed $26.0^{\circ} \mathrm{C}$ (Figure 2).

The water cooler for removing the condensing

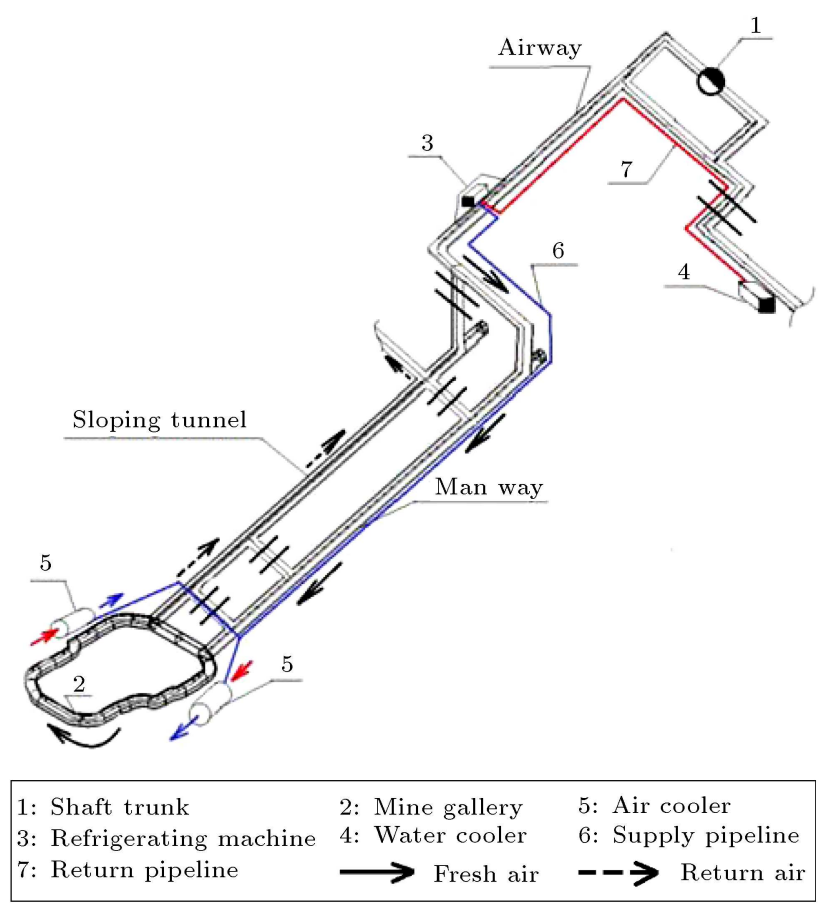

Figure 3. The scheme of arrangement of underground water-cooling refrigerating machines with a capacity of $500 \mathrm{~kW}$ into the mine. 
heat of the refrigerating machine is located in one of the workings located in the immediate vicinity of the air-supplying shaft trunk (Figure 3). The term of commissioning such an ACSMA into operation will not exceed 1 year, given the design, survey, and certification works.

When implementing this approach, the following tasks will be accomplished:

1. Complete normalization of thermal working conditions in the drilling gallery and a significant improvement in thermal conditions in a sloping production in a relatively short amount of time;

2. Training of the personnel of the oil-producing underground enterprise to work with the mine refrigeration equipment and the acquisition of the necessary skills for servicing the ACSMA;

3. Installation and possible operation of refrigeration equipment in specific conditions that are typical of oil mines;

4. Making the final decision on further ways to normalize thermal conditions (surface or underground machines, their power, location, etc.).

The review of the producers of mine refrigeration equipment in the mine explosion-proof execution showed that only the air conditioning mine KShR$350 \mathrm{~N}$, manufactured by NPO Aerosphere (Perm), was produced at present [15]. This air conditioner, designed on the wheelbase for mine conditions, has a rated output of $350 \mathrm{~kW}$. This fact, as well as the overall dimensions and operation principle of KShR$350 \mathrm{~N}$, does not allow recommending it for use in the conditions under consideration.

Of the CIS countries, currently, only the OJSC "Kholod-mash" (Odessa, Ukraine) produces refrigeration equipment. The KPSh300 air conditioner, which is produced by this company, is designed to cool air in coal mines, although it has suitable overall dimensions for the conditions under consideration and, also, cannot be recommended for use due to insufficient cooling capacity and the principle of producing artificial cold [16].

Among European manufacturers, there are such recognized leaders as WAT (Germany), Eurotech, and Termospec (Poland) [17-19]. The produced refrigeration equipment of these companies is characterized by

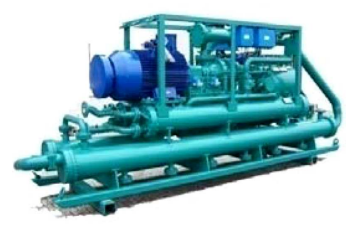

(a)

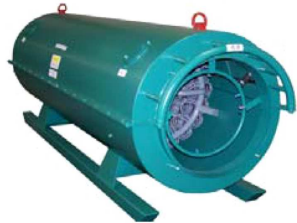

(b)

a wide range of nomenclature that allows satisfying any demand in the required refrigeration capacity. Composition and technical characteristics of the equipment of these companies are approximately the same. It can only be noted that WAT heat exchangers have a cylindrical shape instead of a rectangular one due to the double screw cooling elements (Figure 4), such that the heat transfer coefficient of these devices is much higher and the overall dimensions are smaller, which is an advantage when using them in cramped conditions of underground workings.

The cost of a set of basic refrigeration equipment, for example WAT, which includes a mechanical unit (Figure 4(a)), two air coolers of $250 \mathrm{~kW}$ of cold each (Figure 4(b)), and a 600- kW water cooler (Figure $4(\mathrm{c}))$, is approximately 600 thousand euros. By taking into account design and installation works and the acquisition of auxiliary equipment and materials (pipelines, pumps, water tanks, shut-off valves, etc.), investments in the implementation of the ACSMA will amount to no less than 1 million euros.

To determine the feasibility of investing in the introduction of refrigeration technology in oil mines, we will determine the economic efficiency of the project, provided that the project implementation period is equated to the useful life of the equipment and is assumed equal to 10 years. We will define the changes in the parameters included in the formula of Net Present Value (NPV) as the resultant indicator of the effectiveness of the investment project for 1 year of the project. In constructing the model for determining economic efficiency, the assumption of the invariance of the parameters during the project implementation is used.

1. Changes in revenues due to increased production volumes because of the ability of operators to serve production wells per year more often:

$$
\begin{aligned}
\Delta_{B} & =Q . C . \%_{\text {in }} / 100=150.23,41.0,03.365 \\
& =38450,92 \text { thousand rubles } / \text { year }
\end{aligned}
$$

where:

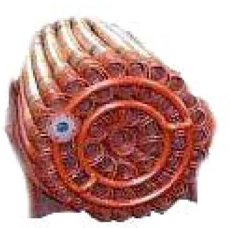

(c)

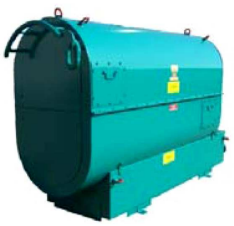

(d)

Figure 4. Refrigeration equipment company WAT: (a) refrigerating machine IDV600, (b) the air cooler RWK250, (c) refrigeration equipment company WAT, and (d) the water cooler RK600. 
$Q \quad$ Daily oil production in the drilling gallery, $t$ (determined based on the annual oil production at the Yaregskoye field [20]);

C Cost of 1 ton of Urals oil, thousand rubles (determined based on the data of the Ministry of Finance for September-October 2017 [21]);

$\%_{\text {in }}$ Percentage of an increase in oil production as a result of working conditions normalization (provisionally accepted 3\%).

2. Change in operating costs:

2.1. As a result of the reduction in the costs of benefits and compensation for work in unfavorable working conditions for the year:

$$
\begin{aligned}
P_{l} & =W_{p} . Z P . \%_{d} / 100=25.57,5.0,4.12 \\
& =6900 \text { thousand rubles }
\end{aligned}
$$

where:

$W_{p}$ The average number of people employed in work performed in mine workings with an air temperature of $+30^{\circ} \mathrm{C}$ or higher (oil production operators);

$Z P$ Average salary of the operator of oil production, thousand rubles (adopted equal to the average wage for workers employed in the work on the extraction of crude oil and natural gas in 2015 [22,23]);

$\% d$ Percentage of surcharges for benefits and compensation for work in unfavorable conditions (provisionally accepted $40 \%$ ).

2.2. As a result of the reduction in the class of working conditions from 3.2 to 2 in a year:

$$
\begin{aligned}
P_{l c} & =W_{p} . Z P . \%_{3.2-2} / 100=25.57,5.0,04.12 \\
& =690 \text { thousand rubles/year, }
\end{aligned}
$$

where $\%_{3.2-2}$ is percentage of surcharge for work in hazardous working conditions (4\%) [24];
2.3. As a result of changes in payments for insurance contributions due to a change in the wage fund:

$$
\begin{aligned}
P_{\text {ins }} & =\left(P_{l}+P_{l c}\right) \cdot \%_{\text {ins }} / 100=7590.0,3 \\
& =2277 \text { thousand rubles } / \text { year, }
\end{aligned}
$$

where $\%_{\text {ins }}$ is insurance premiums $(30 \%)$;

2.4. As a result of changes in payments for insurance contributions in case of accidents due to changes in the wage fund:

$$
\begin{aligned}
P_{\text {ins.n }} & =\left(P_{l}+P_{l c}\right) . \%_{\text {ins. } n} / 100=7590 \cdot 0.085 \\
& =645.15 \text { thousand rubles/year, }
\end{aligned}
$$

where $\%_{\text {ins.n }}$ is insurance contributions in case of accidents (8.5\%);

2.5. As a result of changes in the costs of equipment maintenance, fuel and lubricants, and ordinary repairs:

$$
\begin{aligned}
P_{\text {maint }} & =0,1 . \text { Amortization }=0,1.6870000 \\
& =687 \text { thousand rubles/year. }
\end{aligned}
$$

Expenses for equipment maintenance, fuel and lubricants, and ordinary repairs are taken equal to $10 \%$ of depreciation charges for equipment;

2.6. As a result of a change in the cost of the electricity required for the operation of the $500 \mathrm{~kW}\left(P_{\text {el.c }}\right)$ mine refrigeration equipment per year (Table 2). The electricity cost is accepted according to [25];

2.7. As a result of changes in production costs due to an increase in oil production:

$$
\begin{aligned}
P_{o . p} & =P_{u d} \cdot Q . \%_{i n}=1766,86 \cdot 150.365 .0,03 \\
& =2902 \text { thousand rubles/year, }
\end{aligned}
$$

where $P_{u d}$ is the value of unit costs for oil production is equal to 241 rubles per barrel of oil [26]. In terms of ton, this value will amount to 1.766 .86 rubles/ton.

Table 2. Electricity costs.

\begin{tabular}{lcccc}
\hline Name of the equipment & $\begin{array}{c}\text { Engine power } \\
(\mathbf{k W})\end{array}$ & Quantity & $\begin{array}{c}\text { The electricity tariff } \\
\text { (rub/kW.h) }\end{array}$ & $\begin{array}{c}\text { Energy costs } \\
\text { (rub) }\end{array}$ \\
\hline Refrigerating machine IDV600 & 160 & 1 & 0.96 & 1345536 \\
The air cooler RWK250 & 25 & 2 & & 420480 \\
The water cooler RK600 & 60 & 1 & 504576 \\
Total: & & & $\mathbf{2 2 7 0} \mathbf{5 9 2}$ \\
\hline
\end{tabular}


Thus, the total value of the change in operating costs:

$$
\begin{aligned}
\Delta_{\ni}= & -P_{l}-P_{l c}-P_{\text {ins }}-P_{\text {ins.n }}+P_{\text {maint }} \\
& +P_{\text {el.c }}+P_{\text {o.p }}=-6900-690-2277 \\
& -645.15+687+2270.59+2902 \\
= & -4652.6 \text { thousand rubles/year. }
\end{aligned}
$$

Calculations for the definition of NPV are presented in Table 3. The efficiency calculation was based on the $15 \%$ discount rate accepted by PJSC "LUKOIL" [26]. The conducted calculations also took into account changes in the property tax and income tax. The calculated performance indicators of the investment project are presented in Table 3 . The effectiveness period was determined graphically based on the analysis of the NPV as a cumulative result of time (Figure 5).

On the basis of the obtained indicators (Table 4), we can conclude that it is economically feasible to implement and attract such an investment project, since the value of net discounted income significantly exceeds the zero mark. In addition, estimating the obtained value of the internal rate of return in $59 \%$, we can speak of stability and a sufficiently low risk of the project. The event has a high level of profitability, as evidenced by the high value of the investment return index of 3.48. The pay-off period of the project already occurs in the second year of the project realization. Moreover, the results of the sensitivity analysis performed indicate the sustainability of the project (Table 5 and Figure 6) [27].

Analyzing the data obtained in the course of the risk analysis by the sensitivity analysis method, we can confidently point out the stability of such an investment project and its non-adherence to the

Table 3. The main indicators of the economic efficiency of the project.

\begin{tabular}{lc}
\hline \multicolumn{1}{c}{ Parameter } & The value \\
\hline Net present value (rub) & 136821954.5 \\
IRR (\%) & $59 \%$ \\
DPI (unit) & 2.99 \\
Pay-off period (year) & 2 \\
\hline
\end{tabular}

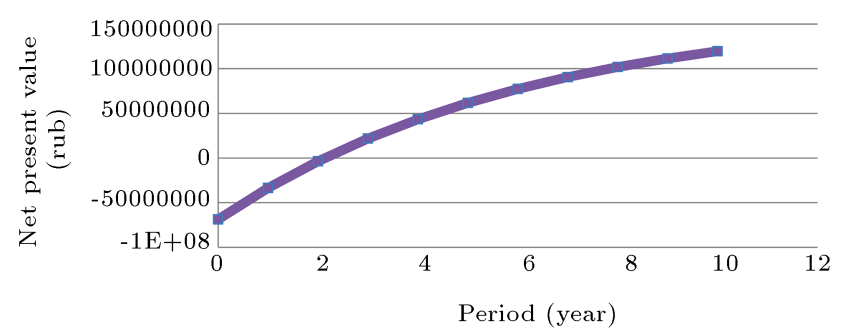

Figure 5. Dependence of the net present value on time.

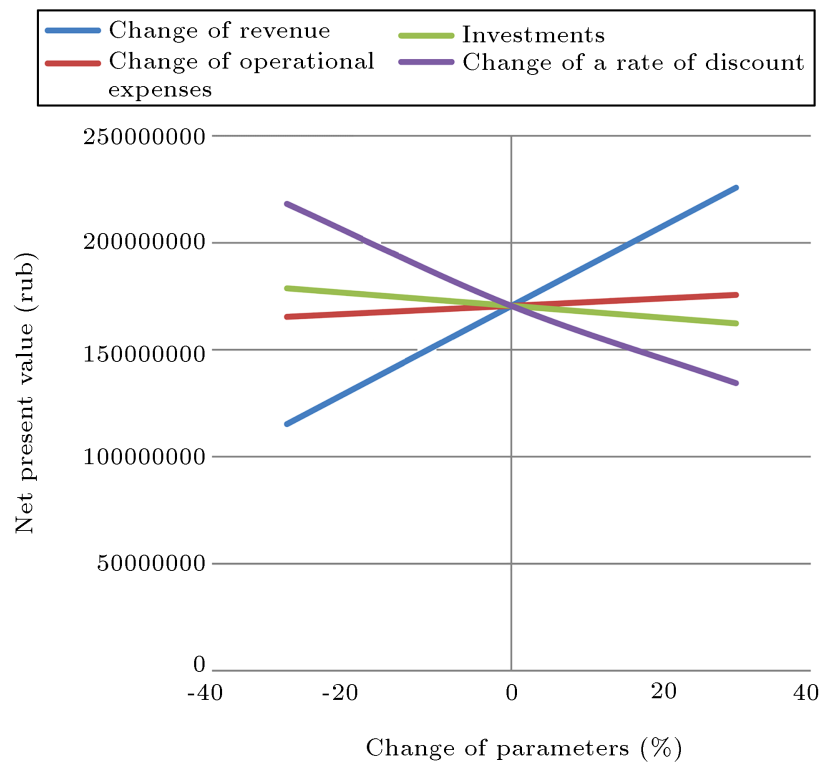

Figure 6. The method of rational ranges.

influence of external factors on the resulting indicator, chosen as the NPV (Figure 5) [28,29]. Based on the results of the performed analysis, it can be said that the project for the implementation of the ACSMA in the oil mine is most sensitive to changes in the revenue parameter. This is also evident both from the graph of the dependence of the NPV on the change in parameters (the line describing the change in the NPV from the change in revenue is steeper than the rest with respect to the horizontal axis) and with a relative change of $-88.63 \%$ (Figure 6 ). However, the significance of the relative change in the revenue parameter tells us that it is very unlikely that such a situation, in which the project is not going to be profitable, will occur. Given the current situation on the world oil market, the level of oil prices will have a minor impact, since the revenue should decrease by almost $100 \%$ in order to make the project unprofitable.

\section{Conclusions}

The research was led to the following outcomes:

1. In the oil well drilling galleries, the values of the heat and humidity parameters of air significantly exceeded the norms permitted by the safety rules. The introduction of an underground water-cooling refrigeration machine with a capacity of $500 \mathrm{~kW}$ ensured the air temperature in the drilling gallery to be compliant with the requirements of safety rules for oil mines;

2. Normalization of thermal working conditions in the drilling gallery reduced the class of working conditions, decreased the costs of benefits and compensation for work in adverse climatic condi- 
Table 4. Economic efficiency of the project.

\begin{tabular}{|c|c|c|c|c|c|c|c|c|}
\hline \multirow{2}{*}{ No. } & \multirow{2}{*}{ Indicator } & \multirow{2}{*}{ Designation } & \multicolumn{6}{|c|}{ Periods (years) } \\
\hline & & & 0 & 1 & 2 & 3 & $\ldots$ & 10 \\
\hline 1 & $\begin{array}{l}\text { Change in revenue } \\
\text { (excluding VAT), rub }\end{array}$ & $\Delta_{B}$ & & 38450925 & 38450925 & 38450925 & 38450925 & 38450925 \\
\hline 1.1 & $\begin{array}{l}\text { The cost of } 1 \text { ton of } \\
\text { Urals oil, rubles/ton }\end{array}$ & & & 23410 & 23410 & 23410 & 23410 & 23410 \\
\hline 1.2 & Increase in production, $t$ & $\begin{array}{l}365 * Q * \% \\
\text { increase }\end{array}$ & & 1642.5 & 1642.5 & 1642.5 & 1642.5 & 1642.5 \\
\hline 2 & $\begin{array}{l}\text { Change in operating } \\
\text { costs, rub }\end{array}$ & $\Delta_{\ni}$ & & -3281340.45 & -3281340.45 & -3281340.45 & -3281340.45 & -3281340.45 \\
\hline 2.1 & $\begin{array}{l}\text { Change in the wage fund } \\
\text { due to the reduction of } \\
\text { costs for benefits and } \\
\text { compensation for work } \\
\text { in unfavorable working } \\
\text { conditions, rub }\end{array}$ & $P_{l}$ & & -6000000 & -6000000 & -6000000 & -6000000 & -6000000 \\
\hline 2.2 & $\begin{array}{l}\text { Change in the wage fund } \\
\text { due to the reduction of } \\
\text { the class of working } \\
\text { conditions from } 3.2 \text { to } 2 \\
\text { per year, rub }\end{array}$ & $P_{l c}$ & & -600000 & -600000 & -600000 & -600000 & -600000 \\
\hline 2.3 & $\begin{array}{l}\text { Change in payments for } \\
\text { insurance contributions } \\
\text { due to a change in the } \\
\text { wage fund, rub }\end{array}$ & $P_{\text {ins }}$ & & -1980000 & -1980000 & -1980000 & -1980000 & -1980000 \\
\hline 2.4 & $\begin{array}{l}\text { Change in payments for } \\
\text { insurance contributions } \\
\text { in case of accidents due } \\
\text { to changes in the wage } \\
\text { fund, rub }\end{array}$ & $P_{\text {ins.n }}$ & & -561000 & -561000 & -561000 & -561000 & -561000 \\
\hline 2.5 & $\begin{array}{l}\text { Change in maintenance } \\
\text { costs for equipment, } \\
\text { fuel and lubricants, } \\
\text { ordinary repairs, rub }\end{array}$ & $P_{\text {maintenance }}$ & & 687000 & 687000 & 687000 & 687000 & 687000 \\
\hline 2.6 & $\begin{array}{l}\text { Change in electricity } \\
\text { costs, rub }\end{array}$ & Pel.c. & & 2270592 & 2270592 & 2270592 & 2270592 & 2270592 \\
\hline 2.7 & $\begin{array}{l}\text { Change in oil production } \\
\text { costs, rubles }\end{array}$ & $P_{u d}$ & & 2902067.55 & 2902067.55 & 2902067.55 & 2902067.55 & 2902067.55 \\
\hline 3 & Investments, rub & & 68700000 & & & & & \\
\hline 4 & Change in taxes, rub & & & 1360260 & 1209120 & 1057980 & 151140 & 0 \\
\hline 4.1 & $\begin{array}{l}\text { Increase in property tax } \\
\text { due to commissioning of } \\
\text { cooling equipment, rub }\end{array}$ & & & 1360260 & 1209120 & 1057980 & 151140 & 0 \\
\hline 5 & $\begin{array}{l}\text { Change in depreciation, } \\
\text { rub }\end{array}$ & & & 6870000 & 6870000 & 6870000 & 6870000 & 6870000 \\
\hline 6 & $\begin{array}{l}\text { Change in profit before } \\
\text { taxation, rub }\end{array}$ & & & 33502005.45 & 33653145.45 & 33804285.45 & 34711125.5 & 34862265.5 \\
\hline
\end{tabular}


Table 4. Economic efficiency of the project (continued).

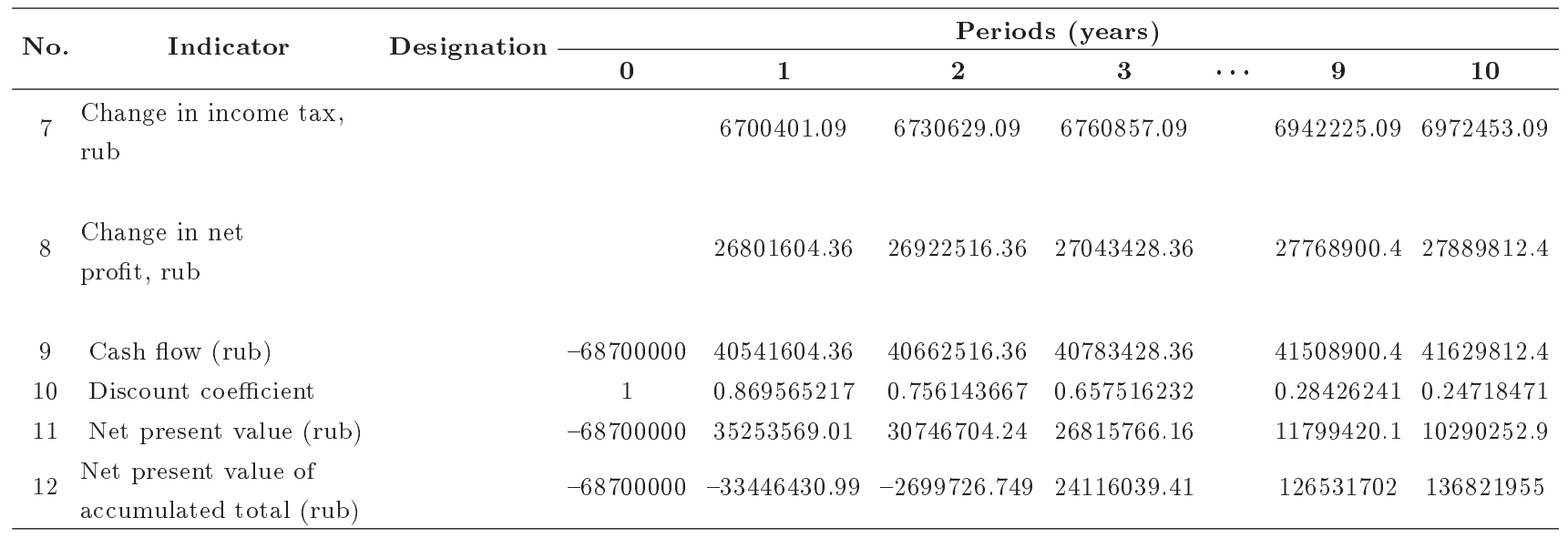

Table 5. Method of control points.

\begin{tabular}{lccc}
\hline \multicolumn{1}{c}{ Parameter } & The base value & The critical value & Relative change (\%) \\
\hline Change in revenue (rub) & 38450925 & 4373320,12 & $-88,63$ \\
Change in operating costs (rub) & $-3281340,45$ & 30796264,11 & $-1038,53$ \\
Investments (rub) & 68700000 & 497398495 & 624,02 \\
Rate of discount (\%) & 15 & 59 & 293,33 \\
\hline
\end{tabular}

tions, increased the production due to the ability of operators to more often serve production wells;

3. On the basis of the obtained indicators, the authors concluded that the value of net discounted income significantly exceeded the zero mark. In addition, estimating the obtained value of the internal rate of return in $59 \%$, we can observe stability and a sufficiently low risk of the project. The project has a high level of profitability, as evidenced by the high value of the investment return index of 3.48 , and the payback will occur in the second year after the introduction of the air-conditioning system.

\section{References}

1. Gerasimov, I.V., Konoplev, Y.P., and Gulyaev, V.E. "Integrated development of the Yaregskoye oil and gas field", The Territory of Oil and Gas, 11, pp. 26-31 (2011).

2. Isayevich, A.G. "Peculiarities of airing oil mines", Strategy and Processes of Development of GeoResources, 10, pp. 247-248 (2012).

3. McPherson, M.J. "Mine ventilation thermodynamics", In Subsurface Ventilation Engineering, Mine Ventilation Services, Fresno, pp. 219-262 (2009).

4. McPherson, M.J. "Subsurface ventilation systems", In Subsurface Ventilation Engineering, Mine Ventilation Services, Fresno, pp. 79-112 (2009).

5. Order of the Federal Service for Ecological, Technological and Nuclear Supervision dated 28.11.2016
No. 501 "On approval of federal norms and rules in the field of industrial safety", Rules for Industrial Safety in the Development of Oil Fields by Mine Method (Registered 21.12.2016 No. 44837). Available at: http://publication.pravo.gov.ru/Document/View/ 0001201612220026 , accessed November 4, 2017.

6. Nor, M.A., Nor, Y.V., and Tskhadaya, N.D. "Sources of heating microclimate in the process of thermal mining development of high-viscosity oil fields", Zapiski Gornogo Instituta, 225, pp. 360-363 (2017).

7. Moziraji, Z.P. and Hannani, S.K. "Analysis and modeling of building thermal response to investigate the effect of boundary conditions", Scientia Iranica, 20(4), pp. 1269-1277 (2013).

8. Mafi, M., Ghorbani, B., Amidpour, M., and Naynian, S.M.M. "Design of mixed refrigerant cycle for low temperature processes using thermodynamic approach", Scientia Iranica, 20(4), pp. 1254-1268 (2013).

9. Sednev, D.Y. "The criterion of length of mine opening by thermal factors at engineering of oil mining unit of oil mines", Actual Problems of Increasing the Efficiency and Safety of Exploitation of Mining and Oilfield Equipment, 1, pp. 205-209 (2015).

10. Jeffrey, R. "Experience and results from using hydraulic fracturing in coal mining", In Proceedings of the 3rd International Workshop on Mine Hazards Prevention and Control, Brisbane, Australia, pp. 110116 (2013).

11. Zhigalov, V.S. "Application of thermal insulation of mine workings in the conditions of oil fields of the 
Yaregskoye field", Strategy and Processes of Development of Geo-Resources, 14, pp. 301-303 (2016).

12. Nasr, T.N. "Heavy oil recovery in Russia: Following the Canadian lead SAGD \& ES-SAGD technologies", Rogtec., 7, pp. 78-85 (2014).

13. Alabiyev, V.R. "The basic directions of development of ways and means of air cooling in coal mines of Ukraine", Bulletin of Transbaikal State University, 6(109), pp. 35-46 (2014).

14. Ministry of Energy and Coal Industry of Ukraine "Forecasting and normalization of thermal conditions in coal mines: SOU-N 10.1.00174088.027-2011" (2011).

15. Levin, L.Yu. "Development of a mine underground air conditioning plant for the conditions of the deep mine «Taimyrsky»", Strategy and Processes of Development of Geo-Resources, 11, pp. 253-255 (2013).

16. Mobile mine air-conditioning KPSH-300. Available at: http://holodmash.od.ua/ru/kpsh-300/ accessed October 21 (2017).

17. Products and services. Available at: http://www.watklima.com/en/products-servic es-23.html accessed October 10 (2017).

18. Eurotech. Available at: http://www.compensus.pl/ eurotech_folder.pdf accessed October 10 (2017).

19. Termospec. Available at: http://www.termospec.pl/ klimatyzacja.html\# accessed October 10 (2017).

20. PJSC "Lukoil". A sea of opportunities. Annual report 2016. Available at: http://www.lukoil.ru/ InvestorAndShareholderCenter/ReportsAndPresentations/ AnnualReports, accessed November 6 (2017).

21. The message of the Ministry of Finance of the Russian Federation, 15.06.2012. Available at: https://

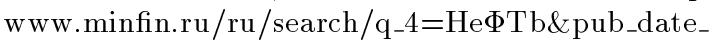
from_4 $=16.10 .2017 \&$ pub_date_to_4 $=16.10 .2017 \&$ page_ id_4=0\&source_id_4=6\#, accessed November 6 (2017).

22. Operational information of the Federal State Statistics Service Data on the wages of employees of organizations by categories of personnel and professional groups of employees for October 2015 (published on 04.04.2016). Available at: http://www. gks.ru/wps/wcm/connect/rosstat_main/rosstat/ru/ statistics/wages/ labour_costs/, accessed November 6 (2017).

23. Hunt, A.P., Parker, A.W., and Stewart, I.B. "Symptoms of heat illness in surface mine workers", International Archives of Occupational and Environmental Health, 85(5), pp. 519-527 (2013).

24. The Labour Code of the Russian Federation. Available at: http://tkodeksrf.ru/, accessed November 6, 2017.

25. Order of the Ministry of Construction, Tariffs, Housing and Communal Services of the Republic of Komi No. 15/1-T "On Establishing Tariffs for Electric Energy (Power) Supplied by the USA Energy Center 000 "LUKOIL-Komi" dated March 20, 2017. Available at: http://docs.cntd.ru/document/446167691, accessed November 6, 2017.
26. PJSC "LUKOIL". Management's analysis of the financial condition and results of operations for 2016, 2015 and 2014. Available at: http://www.lukoil.ru/ FileSystem/PressCenter/93362.pdf, accessed October $23,2017$.

27. Kruk, M.N. and Pavlov, A.N., Possibilities for Assessing Geological and Economic Risks in the Development of Mineral Resources in the Arctic Seas of Russia, RSHU, St. Petersburg (2013).

28. Kruk, M.N. and Nikulina, A.J. "Economic estimation of project risks when exploring sea gas and oil deposits in the Russian arctic", International Journal of Economics and Financial Issues, 6(2), pp. 138-150 (2016).

29. Hechavarría, R., Delgado, O., Hidalgo, A., et al. "Photothermal technique for measuring thermal conductivity and diffusivity of nanofluids a new approach", Periódico Tchê Química, 15(29), pp. 257-266 (2018).

\section{Biographies}

Vadim R. Alabyev graduated from the Leningrad Mining Institute in 1989. He had been working at the Makeevka Research Institute for Mining Safety from 1989 to 2010. He is an expert in the field of normalization of the thermal, ventilation and dust regimes of deep mines. He is an author of more than 60 scientific papers on these topics. He had been working at the mine named after Zasyadko (Donetsk) in 20102016. His responsibilities were to normalize the thermal regime of the mine through the introduction of mining refrigeration equipment. Vadim R. Alabiev has been a Doctor of Technical Sciences since 2016. He has been a Professor of the Department of Life Safety of the Kuban State Technological University since 2016.

Marina N. Kruk graduated from the SaintPetersburg Mining Institute (Technical University) named after G.V. Plekhanov in 2009. She successfully defended her $\mathrm{PhD}$ thesis "Economic evaluation of project risks during the development of offshore gas fields of the Ob Bay" (specialty 08.00.05) in 2012. She is an Associate Professor of the Department of Organization and Management of the Saint-Petersburg Mining University since 2012. Her research interests include the assessment of the economic efficiency of investment projects in the mining and oil and gas complexes, the assessment of the risks of such projects by qualitative and quantitative methods, the assessment of environmental and economic damage, and the issues of corporate social responsibility of companies in the matter of labor protection. Marina N. Kruk is the author of 40 scientific and methodological works.

Tatiana P. Bazhina graduated from the Krasnodar Polytechnic Institute in 1990. She defended her $\mathrm{PhD}$ thesis in 1995. She has been working as an 
Associate Professor at the Department of Life Safety of the Kuban State Technological University since 1996. She deals with the issues of labor protection and the environmental, industrial, and economic safety of mining enterprises. Tatiana P. Bazhina carries out the certification of workplaces at enterprises and organizations in various industries. She underwent professional retraining specializing in "Technosphere safety at work" and refresher courses for persons conducting fire safety measures.

Aleksandr S. Semenov graduated from the SaintPetersburg Mining Institute (Technical University) named after G.V. Plekhanov, where he currently works as an Associate Professor at the Department of Mining Engineering. He is a Candidate of Technical Sciences. He was the winner of the contest "Professional Engineer" in the field of "Mining" in 2016. He has been the Secretary of the Council of the Mining Faculty of the
Saint-Petersburg Mining University since 2017. He is the author of 45 scientific papers including 3 patents for invention, 2 certificates for a utility model, and 5 scientific and methodological works.

Vladimir I. Demin graduated from Kharkov Higher Military Command and Engineering School with a degree in Power Supply of Military Facilities in 1978. He is the Candidate of Technical Sciences, Associate Professor. He has been working as an Associate Professor at the Department of Life Safety in the Kuban State Technological University since 1999. He deals with industrial safety and power supply issues in various industries including the oil and gas industry. He has over 60 publications in this field. Vladimir I. Demin trains workers of enterprises and organizations of the Krasnodar Territory in industrial safety, labor protection, and electrical safety in the framework of additional professional education programs. 